\title{
Ahogy mi ismertük Magdit
}

Az, amit itt olvastok, egy szük baráti-szakmai csoport „pandémiás” online emlékezése Magdira.

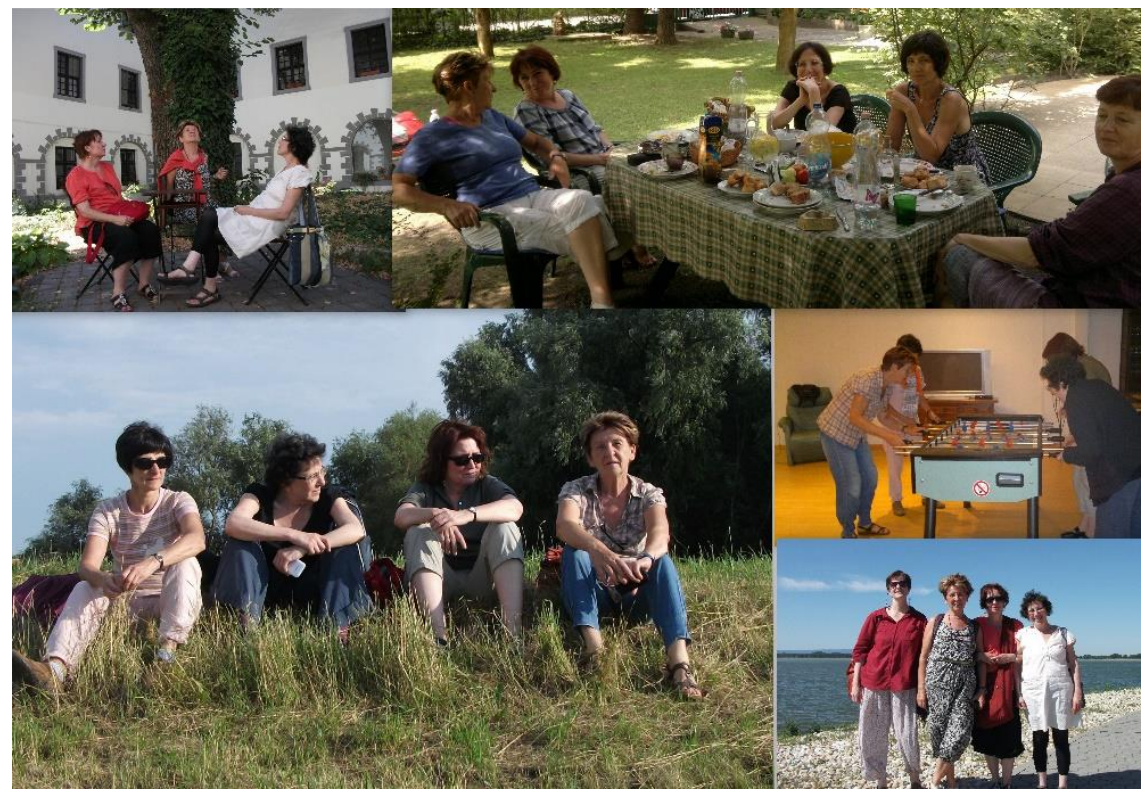

Baráti csoportunk (mi nem túl kreatívan ÖTYÉ-nek hívtuk magunkat, utalva ezzel élemedett korunkra) a szupervíziós képzésen kezdődött. Eleinte Pesten találkoztunk, aztán Magdi egyre kevésbé szívesen jött fel, és akkor mi mentünk Szegedre, vagy félúton Kecskeméten találkoztunk, néha máshol, de erről talán később. Amikor Magdi lánya felvetette, hogy Magdinak - is - fontos volt ez barátság és írjunk róla mi is, éppen karanténban voltunk, így az online beszélgetést választottuk.

Az ÖTYE tagjai: Magdi, Bányai Emőke, Falvai Rita, Tánczos Éva és Aczél Ágnes voltak.

A beszélgetésen hárman vettünk részt: Emő, Rita, Ági, és megpróbáltuk felidézni az emlékeinket Magdiról, milyen volt, amikor berobbant közénk sajátos nevetésével, elárasztott minket ötleteivel, hogy jó, persze szakmázzunk, de mi lenne, ha ide is elmennénk, azt is megnéznénk?

Emő: Ismertük egymást már korábban is, de a szupervíziós képzésen lettünk jóban. A betegségünk kapcsán először ketten beszélgettünk sokat, aztán elmentünk Petrozsénybe kezdte a beszélgetést Emő. Egy következő nagy betegség-hullám előtt már négyen mentünk hozzá látogatni, aztán kitaláltuk, hogy ha már elég jól lesz, hová megyünk még el. És el is mentünk jó párszor kirándulni.

A közös szakmai beszélgetések hoztak össze minket, és szinte észrevétlenül lett komoly, fontos program Magdi látogatása, vagy a találkozó félúton, Kecskeméten. Természetesen sokat beszélgettünk a nagy közösről, a szakmáról, de sok minden másról is.

Rita: Magdi komoly, szívét-lelkét a képzésért, a tudás átadásáért adó szakember, ez volt az egyik lenyügöző oldala. A másik meg, ahogy a különféle technikai eszközöket használta. A 2000-es években mi még döcögve használtuk a technikát, mint amolyan digitális turisták, ő 
meg már akkor virtuóza volt a gépeknek. És már akkor projekt alapon oktatott, amikor ez még csak érintőlegesen jelent meg az oktatásban.

Mindannyian csodáltuk óriási kíváncsiságát, amivel felfedezte az új módszereket, tanulást, tanítást segítő eszközöket, és azt az energiát, amit az órára való felkészülésre fordított. De az igazi „szenvedélye” a tanítványok voltak, akikért minden történik, és akik segítése túlment a tanításon, szakmai- és magánéletükben is számíthattak Magdira, tanácsaira, vagy ha arra volt szükség, a megértésére.

- Fantasztikus volt, hogy teljesen megörizte ezt a kamaszos forradalmár lelkületét, ami a legtöbbünkből kimúlik idővel - próbálja megragadni Ági a számára legjellemzőbbet. - Az az igazságérzet, ahogy Magdi ki tudott állni mindenért, az tényleg kamaszos volt. Ez nekem nagyon fontos benne. A másik meg a szakmai gyakorlattal való kapcsolata. Nemcsak a hallgatókat, hanem az intézményeket is ismerte, folyamatában követte, hogy mi történik a különböző gyakorlati helyeken, mi történik a szakmánk gyakorlatában, ami egyetemi oktatókra nem mindig jellemző.

- Egy kamasz szintjén maradt nyitott mindenre - folytatja Emő. - Sok ember beszükül, ahogy idősödik, de neki hihetetlen sok kapcsolódási pontja volt a legkülönbözőbb dolgokhoz, és ezek igazi, mély kapcsolatok voltak. Ö volt az, akinek nem 24 órája volt egy napban, hanem minimum 60, vagy másnak ennyi kellett volna ugyanannyi dolognak a lebonyolításához vagy karbantartásához, és soha nem éreztem rajta, hogy neki ez erőfeszítés vagy teher. Mint a pillangó, röpködve, nem is tudom, milyen energiatöltésekkel vagy újratöltésekkel.

A konvenciók nem érdekelték, igazából nem is léteztek számára - ez is olyan kamaszos. - A humor, az irónia, az önirónia - még ez is nagyon fontos Magdihoz. És az odafordulás, a nyitottság, hogy dolgunk van, hogy akinek szüksége van, mellé kell állni, közben meg tök kemény volt, kritizált.

- Befözött, eltett, lekvárokat kaptunk tőle, sportolt, tényleg nem tudom, hová fért be ennyi minden - teszi hozzá Rita.

- Hihetetlen nagy kontroll-igénye volt saját magával, és a vele kapcsolatos dolgokkal szemben - egészíti ki Emő. - Mikor már beteg volt, mindig mindent tudni akart. Mással szemben nem, vagy legalábbis én soha nem éreztem, hogy velem szemben kontroll-igénnyel lépett volna fel, de a saját életére vonatkozóan ez nagyon erős volt.

- Felül is bírálta az orvosok döntéseit - szúrja be Ági.

- Sokszor jogosan - jegyzi meg Rita. - Ez segítette, amikor ki tudott lábalni belöle.

- Lehet, hogy ennek a felfokozottságnak volt egy másik oldala is, amit mi soha nem láttunk mondja Emő.

És ebben mind egyetértünk, bár nem láttunk bele. Mi a pozitív oldalát érzékeltük. Rossz kedvünk lehetett, fáradtak lehettünk, ha egy légtérben voltunk Magdival, tudott a magáéból annyit adni, hogy fel tudtunk mi is töltödni, és percek múlva már ott röhögtünk mindenen. Akárhonnan indultunk, egy pár perc vagy egy fél óra alatt át tudott fordulni egy fergeteges nevetésbe.

- Az is elképesztő volt, hogy ilyen nagy betegség közepette vett egy telket, azt csinálta, beiratkozott autós iskolába, megtanult autót vezetni - sorolja Emő. - Emlékeztek, hogy jött a kis autójával, amiben benne volt a hatalmas biciklije, meg a heti biciklitúrára való, mert onnan biciklitúrára ment, annyi holmi volt ott, amit egyikünk se tudott volna betenni abba a kis autóba. És olyan, hogy reménytelen, olyan neki nem volt. Hihetetlen rugalmassággal tervezte 
újra az életet, és egy percig nem éreztem azt az opciót, hogy veszteni lehet. Miközben nyilván megfordult ez is a fejében, de mikor vele voltunk, akkor nekem nem ez az érzésem volt.

- Én már a felidézésbe elfáradtam - mondja Rita. - Annyira tudott élni. Nem a képzésbe, oktatásba begubódzó, száraz, szikár nő volt. Imádott jókat enni, járni kulturális eseményekre, spontán módon részt venni dolgokban. Egyszer dalra fakadt egy múzeum átriumos udvarában, mert jó volt a visszhang.

- Arra emlékszem, mikor Kecskeméten voltunk, és ahogy elment... A mozgásán láttam, hogy baj van - idézi fel Ági.

Ürt hagyott maga után az életünkben, nagyon hiányzik!

Bányai Emöke, Falvai Rita, Tánczos Éva és Aczél Ágnes 